\title{
PARTICULARITIES OF THE POPULATION, OCCUPATION AND STRUCTURE OF UNEMPLOYMENT IN ROMANIA AND ITS WESTERN REGION
}

\author{
Gherghel Silvia, “LucianBlaga”University, Sibiu, graduand, silvia.gherghel@yahoo.com
}

\begin{abstract}
Amid a slow process, but continually aging and a trend of increased migration is a decrease in the active population and employment. Productive structure has undergone several changes in recent years, with a mild increase in service sector, what has changed the occupational structure. The phenomenon of marginalization and poverty has increased especially among groups at risk. Low rates of participation in education and training, at all levels of age, especially in rural areas, generating a low skilled labor in Romania.

Developing regions is not uniform, so that the western region it is noted by a better employment and unemployment default, benefiting from a labor force more flexible, adapt quickly to market requirements, with a high entrepreneurial spirit, against the backdrop of economic growth recorded in the previous years.
\end{abstract}

Keywords : unemployment rate, employment, active population, labor market, labor force

JEL Codes: J62,J64

\section{The participation of the population to the labor force}

Unemployment does not equally affect the different categories of population, nor do the different areas and regions of the country. These aspects will be presented in table 1.

Thus, if we refer to the participation of the population to the labor force, based on gender and areas, between 1996 and 2006 we can notice:

- The active population has been continually decreasing, starting with 2002 . The decrease of active population was of almost 15\% in 2005 compared to 1996 in 1996. The percentage of male population is 50.5 in 1996 and 55.1 in 2005, thus increasing from $49.9 \%$ in 1997 . The urban active population is at an advantage, between 51\% and 54\%, in 2002 and 2003 it recorded a percentage of 51.14 and 51.95 , but a percentage above $54 \%$ throughout the rest of the period.

- The occupied population represents $91-93 \%$ from the active population in the analyzed period, the oscillations being not linear and not in the same direction. The male occupied population was more than $54 \%$ in 2002 compared to almost $50 \%$ before 2000 when the occupied population represented more than half of the active population. The urban occupied population decreased from 54.6\% in 1996 to $53.4 \%$ in 2005, whereas the rural one increased.

- The BIM unemployed, whose number is calculated as the difference between the active and the occupied population, numbers more than 700,000 people, with the exception of 2002 when there were 845,000 unemployed people. The male unemployed population was $68.6 \%$ in 1996 and $59.6 \%$ in 2005 , recording a decreasing trend, but superior to the percentage of female population. The number of the unemployed from the urban areas increased from $50 \%$ in 1996 to $67 \%$ in 2005 , whereas the unemployed from the rural areas decreased at the same rate. 
- The activity and occupation rates are calculated for the population having the right age to work (15-64 years old) and represents numbers between $62-64 \%$ (the activity rate) and under $60 \%$ (the occupation rate). The activity rate, represented on gender, shows an increasing percentage of the masculine one, superior to the feminine one, with a difference of $10-14 \%$; the activity rate in the urban areas decreased in favor of the rural one. The occupation rate records an increase and gender differences, the masculine one increasing in the analyzed period and being superior to the feminine one, with the exception of 1997 when the occupation rate was in favor of the feminine part of the population, recording the highest level $-68.9 \%$ (the reason for this is that this was the peak period of people leaving their jobs and receiving sums of money for compensation; most of these people were men). The occupation rate decreased in the urban areas and increased in the rural ones.

- The BIM unemployment rate recorded levels between $6-8 \%$ during the analyzed period. Men had again a higher percentage than women, but decreased from $9.2 \%$ in 1996 to $7.7 \%$ in 2005. In the urban areas the rate increased from $6.3 \%$ in 1996 to $8.8 \%$ in 2005 compared to the rural area where the rate decreased from $7.3 \%$ in 1996 to $5.2 \%$ in 2005 .

The participation of the population to the labor force

Table no. 1. 


\begin{tabular}{|c|c|c|c|c|c|c|c|c|c|c|c|c|}
\hline $\begin{array}{l}\text { Population } \\
\text { (thousands of } \\
\text { people) }\end{array}$ & \multicolumn{2}{|l|}{1996} & \multicolumn{2}{|c|}{1997} & \multicolumn{2}{|c|}{2002} & \multicolumn{2}{|c|}{2003} & \multicolumn{2}{|c|}{2004} & \multicolumn{2}{|c|}{2005} \\
\hline $\begin{array}{l}\text { Active } \\
\text { population - } \\
\text { total }\end{array}$ & \multicolumn{2}{|c|}{11.726} & \multicolumn{2}{|c|}{11.756} & \multicolumn{2}{|c|}{10.079} & \multicolumn{2}{|c|}{9.915} & \multicolumn{2}{|c|}{9.957} & \multicolumn{2}{|c|}{9.851} \\
\hline $\begin{array}{l}\text { On genders: } \\
\text { M,F }\end{array}$ & nิ & $\frac{2}{2}$ & $\underset{⿱ 亠}{\infty}$ & $\begin{array}{l}\text { N } \\
\infty \\
\infty\end{array}$ & $\begin{array}{l}n \\
n \\
n\end{array}$ & $\stackrel{+}{n}$ & $\begin{array}{l}n \\
\vdots \\
i\end{array}$ & $\stackrel{8}{i}$ & 芯 & $\begin{array}{l}\infty \\
\stackrel{\infty}{+}\end{array}$ & $\underset{n}{n}$ & 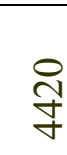 \\
\hline $\begin{array}{l}\text { On areas: } \\
\text { Urban, rural }\end{array}$ & 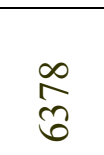 & $\stackrel{\infty}{\infty}$ & 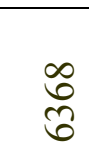 & $\begin{array}{l}\infty \\
\infty \\
i n\end{array}$ & $\begin{array}{l}\infty \\
\infty \\
\infty\end{array}$ & $\vec{a}$ & $\frac{\bar{n}}{n}$ & $\frac{\text { t }}{\stackrel{f}{f}}$ & $\stackrel{\overbrace{}}{\stackrel{n}{n}}$ & $\stackrel{+}{n}$ & $\begin{array}{l}\vec{b} \\
\cdots \\
n\end{array}$ & ஓ̊̊ \\
\hline $\begin{array}{l}\text { Occupied } \\
\text { population- } \\
\text { total }\end{array}$ & \multicolumn{2}{|c|}{10.935} & \multicolumn{2}{|c|}{11.050} & \multicolumn{2}{|c|}{9.234} & \multicolumn{2}{|c|}{9.223} & \multicolumn{2}{|c|}{9.158} & \multicolumn{2}{|c|}{9.147} \\
\hline $\begin{array}{l}\text { On gender: } \\
\text { Masculine } \\
\text { Feminine }\end{array}$ & 舷 & $\stackrel{n}{n}$ & $\stackrel{n}{n}$ & $\underset{\infty}{n}$ & in & $\stackrel{\Re}{\stackrel{\overbrace{}}{f}}$ & $\hat{n}$ & $\frac{\oslash}{\underset{\gamma}{\sigma}}$ & $\begin{array}{l}\stackrel{\infty}{\infty} \\
\stackrel{+}{+}\end{array}$ & $\stackrel{\infty}{\frac{\infty}{7}}$ & 쿠 & 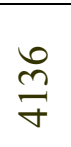 \\
\hline $\begin{array}{l}\text { On areas: } \\
\text { Urban, rural }\end{array}$ & $\frac{a}{5}$ & $\begin{array}{l}\stackrel{0}{2} \\
\stackrel{+}{q}\end{array}$ & ষ্ঠ & $\begin{array}{l}0 \\
\text { ப̊ } \\
\text { in }\end{array}$ & ô & సิ & $\begin{array}{l}\text { రి } \\
\text { tे }\end{array}$ & 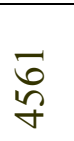 & ஓ & 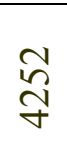 & $\begin{array}{l}\infty \\
\infty \\
+\infty\end{array}$ & $\stackrel{\infty}{\stackrel{\infty}{f}}$ \\
\hline $\begin{array}{l}\text { BIM } \\
\text { unemployed }\end{array}$ & \multicolumn{2}{|l|}{791} & \multicolumn{2}{|l|}{706} & \multicolumn{2}{|c|}{845} & \multicolumn{2}{|l|}{692} & \multicolumn{2}{|l|}{799} & \multicolumn{2}{|l|}{704} \\
\hline $\begin{array}{l}\text { On gender: } \\
\text { Masculine } \\
\text { Feminine }\end{array}$ & $\stackrel{m}{n}$ & $\stackrel{\infty}{\sim}$ & $\hat{a}$ & ஓे & 守 & $\bar{n}$ & $\stackrel{\infty}{\stackrel{9}{q}}$ & $\underset{\sim}{\sim}$ & $\bar{g}$ & $\stackrel{\infty}{\infty}$ & $\stackrel{\text { }}{\text { f }}$ & 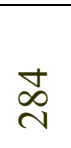 \\
\hline \multicolumn{13}{|c|}{ Percentage of rates, per total } \\
\hline Activity rate & \multicolumn{2}{|c|}{$64,8 \%$} & \multicolumn{2}{|c|}{$64,8 \%$} & \multicolumn{2}{|c|}{$63,6 \%$} & \multicolumn{2}{|c|}{$62,4 \%$} & \multicolumn{2}{|c|}{$63,2 \%$} & \multicolumn{2}{|c|}{$62,4 \%$} \\
\hline Occupation rate & \multicolumn{2}{|c|}{$60,4 \%$} & \multicolumn{2}{|c|}{$60,9 \%$} & \multicolumn{2}{|c|}{$58 \%$} & \multicolumn{2}{|c|}{$57,8 \%$} & \multicolumn{2}{|c|}{$57,9 \%$} & 57,70 & \\
\hline $\begin{array}{l}\text { BIM } \\
\text { unemployment } \\
\text { rate }\end{array}$ & $6,7^{0}$ & & $6,0 \%$ & & $8,4^{\circ}$ & & $7,0 \%$ & & $8,0 \%$ & & $7,2 \%$ & \\
\hline
\end{tabular}

Source: The enquiry of the labor force in households

In 2006 the number of unemployed people increased to 728, 000 people and the rate of BIM unemployment to $7.3 \%$, a level close to that reached previously $(7.2 \%)$, as indicated by the data from the National Institute of Statistics.

On gender, the unemployment rate was higher among men $(8.2 \%)$ and lower among women $(6.1 \%)$. On residential areas, unemployment recorded higher rates in the urban areas $(8.6 \%)$ and lower ones in the rural ones $(5.6 \%)$.

On age groups, the BIM unemployment rate had the highest level (21\%) among young people $(15-24$ years old). Thus, unemployment affected the high school and lower secondary graduates to a greater extent; the rate was $7.8 \%$ and $7.6 \%$ compared to $3.8 \%$ - the rate recorded among university unemployed graduates.

The BIM long-term unemployment rate, which refers to people who are unemployed for more than a year, was $4.1 \%$. The percentage of people unemployed for more than a year was $56.1 \%$ in 2006 and was felt mostly among people from the rural areas $(57.5 \%)$ compared to $55.3 \%$ in urban areas. The gender differences were even sharper (57.4\%-men and 53.8\%-women). 
For young people (15 - 24 years old) the rate of long-term unemployment (unemployed for more than 6 months) was $14.2 \%$ and the incidence of long-term unemployment among youngsters was $67.4 \%$.

The employed people recorded in 2006 numbered 6,003 (industry + constructions $-2,588$; services-3,287; agriculture- 128; other categories- 3,092).

In 2007 the occupation rate of the population having the right age to work $(15-64$ years old) was $57.9 \%$ whereas the BIM unemployment rate decreased to $6.1 \%$ (the number of BIM unemployed decreased to 599,000 people) from $7.2 \%$ in the previous year. The level of the occupation rate is situated at a distance of $12.1 \%$ from the $70 \%$ target settled for 2010 by the Lisbon Strategy.

On gender, the difference between the two rates of BIM unemployment was $2.3 \%(7.2 \%$ for men and $4.9 \%$ for women); on residential areas the difference was of $2.7 \%(7.3 \%$ for urban areas and $4.6 \%$ for rural ones). The level of BIM unemployment had the lowest level $(18.9 \%)$ among young people ( $15-24$ years old).

The levels recorded in 2006 and 2007, on categories of population are presented in Table 2.

Table no. 2.

The situation in 2006 and 2007 on categories of population

\begin{tabular}{|l|c|c|}
\hline Categories of population (thousands of people) & 2006 & 2007 \\
\hline Total population & 21.584 & 21.538 \\
\hline I5-year olds and above & 18.250 & 18.249 \\
\hline Population under 15 & 3.334 & 3.289 \\
\hline $\begin{array}{l}\text { Active population (occupied population + BIM } \\
\text { unemployed }\end{array}$ & 9.802 & 9773 \\
\hline 15-yearl old and above inactive population & 8.448 & 8476 \\
\hline Occupied population (employed + other categories) & 9.095 & 9.174 \\
\hline BIM unemployed & 707 & 599 \\
\hline
\end{tabular}

Source: Press release no 77, 23 ${ }^{\text {rd }}$ April 2007 and no 62/31 ${ }^{\text {st }}$ March 2008 regarding the occupation and unemployment - The National Institute of Statistics ( Statistic research of the labor force in households - AMGO, 2006 - 2007).

The categories of population are presented in a graphic nr.3 as following:

Table no. 3 .

The categories of population

\begin{tabular}{|c|c|c|c|}
\hline \multicolumn{4}{|c|}{ Total population } \\
\hline \multicolumn{3}{|l|}{ 15-year-olds and above } & Younger than 15 \\
\hline \multicolumn{2}{|l|}{ Active population } & $\begin{array}{l}\text { 15-year old and above } \\
\text { inactive population }\end{array}$ & \\
\hline Occupied population & $\begin{array}{l}\text { BIM } \\
\text { Unemployed }\end{array}$ & & \\
\hline Employed & Other categories & & \\
\hline Ind.+constr. + services + agricult. & & & \\
\hline
\end{tabular}

Source: www.insse.ro - The statistic research upon the labor force in households - AMIGO, 2006 2007

In the graphic:

- The population active from an economic point of view consists of all the people who provide the labor force available for the production of goods and services, during the referred period, including the occupied and unemployed population; 
- The occupied population consists of all the people older than 15 who have unfolded an economic activity producing goods or services at least an hour (for people working on their own and those working in the agricultural field without being remunerated - the minimum period is 15 hours) during the referred period (one week), with a view to obtain income in the form of salaries or other benefits;

- The BIM unemployed are the people aged 15-74 who meet the following requirements: (i) they don't have a work place; (ii) they are willing to start work in the following two weeks; (iii) they have actively looked for a work place in the last four weeks.

Romania's population has been in a slow but continuous decreasing process starting with 1990, reaching 23.4 million in 2001.

The population having the proper age to work (15-64) has remained stable, approximately 15.3 - 15.4 million. By 2020 the population will have decreased with 1.8 million and the decrease will mostly affect the young-aged groups (10-24).

According to the first enquiry upon the labor force in 1994, the participation rate (for those between 15 and 64) was $69.7 \%$, then it increased in 1996 to $72.3 \%$, then it decreased to $68.5 \%$ in 2001 , i. e under the U. E. rate of $69.2 \%$. The rate of activity of the female population is $12 \%$ lower than the male one. The decrease of participation affected mostly the young age group. An important decline was recorded in the $45-54$ age group, whereas the rate of activity for the $55-64$ group was slightly higher in 2001 (51\%) compared to 1994 (50\%). A characteristic of the participation in Romania is the high rate of activity of the population aged 65 and older. The phenomenon can be explained through the place agriculture holds in the Romanian economy.

In 2006, according to the data offered by The National Institute of Statistics, the occupation rate of the population having the proper age to work $(15-64)$ was $58.8 \%, 1.1 \%$ more than 2005 and $11.2 \%$ lower that the target set for 2010 by the Lisbon Strategy.

The occupation rate for the population having the proper age to work had higher values for men $(64.7 \%$ compared to $53 \%$ for women), and for the people in the rural areas $(61.1 \%$ compared to $57.2 \%$ for those in urban areas). The occupation rate was $41.7 \%, 8.3 \%$ lower than the target set for 2010 by the Lisbon Strategy.

Compared to 2005, the most significant increase of the occupation rate in 2006 was recorded among the elderly $(55-64)$ in the urban areas $(+5.1 \%)$, whereas for the young population $(15-24)$ in the rural areas the rate recorded the sharpest decrease $(-1.7 \%)$.

The highest level of the occupation rate for the people having the right age to work was recorded among university graduates $(86.1 \%)$. The lower the level of education, the lower the occupation rate. Thus, among the people who only graduated high schools the rate was $64.9 \%$ and for those with a lower level of education the rate was $39.6 \%$.

The employees still hold the majority of the occupied population $(66.2 \%)$, their number increasing with 264,000 compared to the previous year. In 2006 the people working on their own or for family associations represented $32.1 \%$ of the occupied population.

The division into groups of occupation reveals the fact that agriculture and the people qualified to work in agriculture, forestry, and fishing represent $24.9 \%$ of the total of occupied population, decreasing as compared to the previous year. A better position $(16.5 \%)$ was held by such categories as handicraftsmen and workers skillful in jobs implying craftsmanship. Compared to 2005 , the number of specialists and university graduates rose significantly $(+8.9 \%)$ and so did the number of technicians, foremen and assimilated $(+7.3 \%)$.

The division of occupied population into activities of the national economy reveals that $30.5 \%$ of the occupied people were concentrated in the agricultural sector, $30.6 \%$ in industry and constructions, and $38.9 \%$ in services. 
Compared to 2005 the number of occupied people in the fields of real estate transactions, renting and services performed within industries $(+21.5 \%)$, constructions $(+10.1 \%)$, as well as transports, storing, and communications $(+9.3 \%)$.

\section{The labor force of the Western region}

Among the 8 development regions (North-East; South-East; South-Muntenia; South-West Oltenia; West; North-west; Centre; Bucharest-Ilfov), the Western region (Timis, Caras-Severin, Arad, Hunedoara Counties) records:

- $\quad$ A decrease of the active population, both on gender and areas, increasing in the case of men, compared to women, and to a greater extent in the urban areas compared to the rural ones;

- $\quad$ A decrease of the occupied population, both on gender and areas, decreasing and higher for the male population and higher for the urban areas but lower for the rural ones;

- $\quad$ The BIM unemployed represent 67,000 people in 1996 and 57,000 in 2005, higher for men but decreasing; the unemployment rate is higher in the urban areas, but decreasing.

- The activity, occupation and BIM unemployment rates are within the numbers recorded in the whole country, with differences of $1-2 \%$ during the analyzed period. The occupation and BIM unemployment rate in the Western region are higher at the end of the period compared to the occupation and unemployment rates at a national level, which represents a promising tendency.

The labor force of the region represents the factor that contributed to the socio-economic development the most, being motivated, flexible, and innovative, with a high degree of specialization, thus contributing to the development of a dynamic entrepreneurial medium.

In 2005 the occupied population represented $40.8 \%$ of the total, the highest percentage being in the tertiary sector $(43.8 \%)$, followed by industry $(29.5 \%)$ and agriculture $(26.6 \%)$. The occupied population has the highest values in Timis (48.3\%) and Arad (44.1\%).

The occupied population in the industrial sector decreased significantly between 1993 2003, especially in industrialized counties- Hunedoara and Caras-Severin-, especially as a result of workers from mining and siderurgy leaving their jobs and receiving money as compensation. Thus the population had to orientate mainly towards the services sector.

The unemployment rate knew fluctuations between $1991-2005$, from $2.5 \%$ in 1991 to $5.1 \%$ in 2005 . The highest value of the unemployment rate is recorded in Hunedoara County $(9.4 \%)$, and the lowest one in Timis County.

After 1990, the possibility to leave the country and work abroad appeared, so a number of specialized people left the country, following old traditional relations towards Germanic countries and Hungary. These specialists are needed today when more and more important investors found industries in this region.

The eight development areas are not uniform; the Western area does not represent the eighth part, it participates with less than $12.5 \%$, which would be the percentage allotted to each region in case of a uniform division of unemployment on areas.

\section{Conclusions}

In 2006, 2007 the recorded unemployment followed the same line started in 2004 of flattening the unemployment curve and maintaining its level below the level of past years.

The occupation and unemployment in Romania knew significant changes during the period of economic transition, manifesting differences regarding gender and areas. 
Thus, approaching the labor force from a gender perspective, after 2005 the occupation rate was higher for men as compared to women. The participation of men and women on the labor market is connected with their level of education, the correlation being stronger in the case of women. Women are slightly underrepresented on the labor market also because of their early retirement. This is how the fact that between 2000-2006 there was a difference of $11-12 \%$ between men and women, aged 15-64 can be explained.

The BIM unemployment rate recorded values between $7-8 \%$ in the $2002-2007$ period, as follows: the rate in case of women was more than one percent lower than in the case of men. Longterm unemployment also knew an increasing trend in the case of men (from $3.1 \%$ to $4.5 \%$ in the case of men and from $3 \%$ to $4 \%$ in the case of women).

The major cause of the tendency of reducing the occupation was the fact that the economy lost an important sector that generated work places - industry-, without developing another (services or agriculture) as there was no flow from one sector to another. Another cause of the decrease of the occupied population segment was represented by the new regulations that allowed early retirement. The migration of the Romanian towards other countries of Europe, and not only, also contributed to the decrease of the occupied active population.

The lowest levels of unemployment in the last years can be explained by the continuous economic development recorded especially after 2004. Beside the economic growth recorded at a national level, there were other factors that contributed to maintaining a low rate of unemployment; for example, the consistent application of the active measures meant to lead to the increase of occupation and decrease of unemployment. The legislative instrument used was the law regarding the insurance system for unemployment and the stimulation of occupation of the labor force (76/2002).

\section{References:}

1. Oprescu Gheorghe - Labor market - theories, policy, transition in Romania, Publishing Expert, Bucureşti, 2001.

2. Perț Steliana - Labor market in România. Employment, flexibility, human development, CIDE, Bucureşti, 2000.

3. Ristea Cristache - coordonator, Management employment - Labor market and training, volume1, part I, ANOFM -CNFPPP Râşnov, 2007

4. www.insse.ro

5. www.anofm.ro

6. www.fse.anofm.ro

7. www.mmssf.ro

8. www.euractiv.ro 